ORIGINAL ARTICLE

\title{
Markers of local immunity in cervico-vaginal secretions of HIV infected women: implications for HIV shedding
}

\author{
F Zara, R E Nappi, R Brerra, R Migliavacca, R Maserati, A Spinillo
}

Sex Transm Infect 2004;80:108-1 12. doi: 10.1136/sti.2003.005157

See end of article for authors' affiliations

.............

Correspondence to: Arsenio Spinillo Departmenbt Ob/Gyn, Policlinico $S$ Matteo,

Piazzale Golgi 2, 27100 Pavia, Italy;

spinillo@smatteo.pv.it

Accepted for publication 9 October 2003

\begin{abstract}
Objectives: To link local proinflammatory cytokines with HIV related nucleic acids in cervico-vaginal secretions and the factors associated with them.

Methods: An observational study on 60 HIV positive women attending the department of obstetrics and gynaecology, University of Pavia, Italy. HIV-1 RNA in plasma, proviral HIV-1-DNA, cell associated and cell free HIV-1 RNA in cervico-vaginal secretions were evaluated by competitive polymerase chain reaction (c-PCR) and reverse transcriptase PCR (cRT-PCR). IL-1 $\beta$, IL-6, and TNF- $\alpha$ were measured by ELISA in cervico-vaginal lavages. Multiple regression analysis on ordinal categorical variables was used to test for the simultaneous associations of clinical and microbiological variables on quartiles of cytokine concentrations in lavage samples.

Results: Proviral HIV-1 DNA, cell associated and cell free HIV-1 RNA were detected in 76.7\% (46/60), $70 \%(42 / 60)$, and $71.7 \%(43 / 60)$ of the patients, respectively. IL-1 $\beta$ concentration was directly correlated with proviral HIV-DNA (Spearman $r h o=0.35, p=0.01$ ) and cell associated HIV-RNA levels (Spearman rho $=0.263, p=0.05)$. IL-1 $\beta$ concentration $(153.9 \mathrm{pg} / \mathrm{ml})$ was higher $(p<0.05)$ among women with cytological squamous intraepithelial lesion (SIL) than negative controls $(73.4 \mathrm{pg} / \mathrm{ml})$. In women with vaginal infection both $\mathrm{IL}-1 \beta(41.7 \mathrm{pg} / \mathrm{ml})$ and $\mathrm{IL}-6(10.2 \mathrm{pg} / \mathrm{ml})$ were lower $(\mathrm{p}<0.05)$ in comparison to negative controls $(144.9 \mathrm{pg} / \mathrm{ml}$ and $23.7 \mathrm{pg} / \mathrm{ml}$, respectively). Women receiving stable antiretroviral therapy had significantly lower TNF- $\alpha(34.4 \mathrm{pg} / \mathrm{ml}$ versus $44.4 \mathrm{pg} / \mathrm{ml}, \mathrm{p}=0.04)$ and higher IL-6 $(24.0 \mathrm{pg} / \mathrm{ml}$ versus $1.4 \mathrm{pg} / \mathrm{ml}, \mathrm{p}=0.004)$ levels in lavage samples compared to untreated women. The associations between the presence of SIL, antiretroviral treatment, vaginal infection and cytokine concentrations in cervico-vaginal secretions were confirmed in multiple regression analysis.

Conclusions: Local immune activation may modulate HIV-1 shedding in cervico-vaginal secretion with possible influence on vaginal physiology and host defence. Pharmacological agents lowering HIV-1 replication cause a shift to a pattern of cytokine production which seems less favourable to the transmission of the disease.
\end{abstract}

$\mathrm{T}$ he female genital tract is a reservoir of human mmunodeficiency virus type 1 (HIV-1). The common mucosal immune system and cellular immune components contribute to immune response against HIV-1 in the female genital tract. ${ }^{2}$ Indeed, a complex cascade of host proinflammatory and immunoregulatory cytokines detected in the cervico-vaginal secretions of uninfected and HIV-1 infected women modulates HIV-1 replication. ${ }^{3}{ }^{4}$ Moreover, local immune activation increases HIV-1 load in genital secretions, potentially enhancing the risk of sexual transmission of HIV- $1 .^{5}{ }^{6}$

We have previously shown the relevance of the detection and quantification of HIV-l related nucleic acids in cervicovaginal secretions. ${ }^{7}$ However, despite the progress towards the understanding of the factors responsible for HIV shedding in the lower female genital tract, little is known regarding the regulation of local immune responses in the female genital tract.

Modulation of local cytokine expression by inflammatory stimuli or pharmacological agents may affect HIV-1 replication in the genital secretions and, therefore, influence the susceptibility to sexually transmitted infections (STIs). ${ }^{8}$

The aim of this study was to link local proinflammatory cytokine concentrations with HIV-1 related nucleic acid load in cervico-vaginal secretions of HIV infected women.

\section{METHODS}

\section{Study population}

From a cohort of known HIV-1 seropositive women followed at our department in the period June 2000-May 2001 for cytological screening for lower genital tract neoplasia, 63 non-pregnant HIV-1 seropositive women were recruited for this study, after they had signed informed consent. None had unprotected sexual contacts at least 3 days before the observation. A demographic and clinical questionnaire was administered to each participant. Clinical HIV staging was defined using the Centres for Disease Control (CDC) classification system. ${ }^{10}$

\section{Study protocol}

Blood and cervico-vaginal samples were obtained on the same day. Blood sample analysis included CD4+ lymphocyte cell counts and plasma HIV-RNA. After careful speculum examination, vaginal swabs were collected to diagnose infection by candida, trichomonas, or bacterial vaginosis. ${ }^{7}$ To evaluate candida infection, vaginal specimens were inoculated on Sabouraud dextrose agar containing gentamicin $(40 \mathrm{~g} / \mathrm{ml})$. The isolated strains were identified with either the germ tube test or by auxanogram (API 20 Aux; API system, Montalieu-Vercieu, France). Vaginal specimens for trichomonas isolation were inoculated in a cysteine-peptoneliver maltose fresh medium, whereas the diagnosis of 
bacterial vaginosis was made according to the criteria of Amsel et al. ${ }^{11}$

Cervico-vaginal secretions were obtained by a gentle rotation of a Dacron swab within the posterior fornix. In addition, a lavage was performed with $10 \mathrm{ml}$ of RPMI 1640 medium into the vagina, followed by aspiration of the suspension after allowing 1 minute for pooling. Swabs were used to detect cell free HIV-RNA, while HIV-DNA, intracellular HIV-RNA transcripts, human papillomavirus (HPV)DNA, and cytokines were measured from lavage samples. Finally, a Papanicolaou smear and a standard colposcopic examination were carried out. Cervical samples were examined under the microscope to confirm absence of red blood cells and spermatozoa and tested for the presence of blood contamination (reactive strips, Bayer, multistic-10 visual). Three patients were excluded from the study because cervical specimens contained haemoglobin, thus leaving 60 patients for the final analysis.

\section{HIV related nucleic acid measurements}

A detailed description of the methods used to detect and quantify HIV related nucleic acids both from blood and cervico-vaginal secretions has previously been reported. ${ }^{12}$ The supernatant from the swab was used to extract cell free HIVRNA. HIV-DNA was extracted from the nuclei of cervicovaginal cells to minimise contamination with unintegrated DNA. RNA was extracted using the guanidinium thiocyanate method. ${ }^{13}$ The following substrates were analysed using quantitative polymerase chain reaction (CPCR) and reverse transcription (RT)-PCR: (a) genomic HIV-RNA from plasma and cell free cervico-vaginal secretions; (b) virus specific unspliced HIV-RNA transcripts from cervico-vaginal cells; (c) proviral HIV-DNA from cervico-vaginal cell nuclei. Qualitative analysis of specific HIV-DNA and RNA sequences was first conducted by PCR and RT-PCR using the SK 426/ 431 pair of primers. ${ }^{14}$

Quantification of DNA and RNA was performed using the primer set SK38/39 by competitive PCR and RT-PCR as described by Menzo et al. ${ }^{15}$ Quantitative results were expressed as HIV-RNA transcripts and HIV-DNA copy number per $10^{5}$ cells, and as HIV-RNA cell free copy number per $\mathrm{ml}$ of cervico-vaginal secretions. Swabs were incubated in a predefined quantity of transport medium ( $1 \mathrm{ml}$ ), so it was possible to know the exact amount of cervico-vaginal secretion present in each sample (usually 200-300 $\mu \mathrm{l}$ ). In our experimental conditions, the lower limit of detection of the assay was two DNA or RNA copies $/ 10^{5}$ cells, 20 RNA copies/ml of cervical secretions, and 200 RNA copies/ml of plasma.

HPV-DNA extraction and PCR were done on lavages as previously described. ${ }^{16}$ HPV-DNA typing on positive samples was done with the "Multigen HPV" commercial kit (DiaTech, Jesi, Italy), which is based on the amplification of a 142151 bp fragment of the Ll region by PCR and subsequent restriction fragment length polymorphism (RLFP) analysis of PCR products. The digestion pattern can yield human papillomavirus (HPV) types 6, 11, 16, 18, 31, 33, 35, and 56.

\section{Cytokines assay}

Quantitative enzyme linked immunosorbent assay (ELISA) kits (Chemicon International, CA, USA) were used to measure the concentrations of tumour necrosis factor (TNF)- $\alpha$, interleukin (IL)-1 $\beta$ and IL-6 in the cervico-vaginal supernatants. After testing the assay kit according to the manufacturer's instructions, a dilution factor was necessary to measure IL- $1 \beta$ and TNF- $\alpha$ (lower limits of detection were $1.95 \mathrm{pg} / \mathrm{ml}$ for both) and IL-6 (lower limit of detection was $0.34 \mathrm{pg} / \mathrm{ml}$ ). All samples and controls were assayed in duplicate. The TNF- $\alpha$ assay was performed immediately after the sample process, given the intrinsic instability of such a cytokine. The intra-assay and inter-assay coefficients of variation of TNF- $\alpha$ were $6.5 \%$ and $11.7 \%$, respectively, for IL- $1 \beta$ they were $8.1 \%$ and $11.7 \%$, respectively and for IL-6 they were $8.1 \%$ and $10.4 \%$, respectively. A value of zero was assigned to any cytokine result that was below the assay's lower limit of detection.

\section{Statistical analysis}

Since the data were skewed a non-parametric approach (Mann-Whitney U test and Spearman rank correlation coefficient) was used to analyse continuous variables. Categorical analysis was carried out by Fisher's exact test and by computation of odds ratio and 95\% confidence intervals. To evaluate the simultaneous associations of clinical and microbiological variables on the cytokine concentration of lavage samples we used stepwise multiple regression models on ordinal categorical variables. For this purpose the concentrations of cytokines in cervico-vaginal lavages were expressed as quartiles of concentration and inserted in the model as dependent categorised ordinal variables. In this kind of analysis numerical variables are expressed as categories and no distributional assumption about the variables is made. Independent variables were inserted either as categorised ordinal variables on the basis of quartile of concentration (HIV related nucleic acids in plasma and cervico-vaginal lavage) or counts (CD4+ cell counts) or as dichotomous variables (vaginitis, squamous intraepithelial lesion, genital HPV infection and antiretroviral treatment). Only variables significantly associated $(\mathrm{p}<0.05)$ with quartiles of cytokine concentration are present in final models. Statistical analysis was performed using SPSS statistical software (SPSS Inc, Chicago, IL, USA).

\section{RESULTS}

The mean age of the study population was 30.7 (SD 3.8 ) years. Injecting drug use was the main risk factor for HIV acquisition in 22 patients $(36.7 \%)$; in the remaining patients HIV infection was heterosexually transmitted. The prevalence of cigarette smoking was $71.7 \%(41 / 60)$ and 10 women $(13.3 \%)$ had more than one sexual partner in the 6 months preceding the study. Regarding the contraceptive method used, 22 patients $(36.7 \%)$ did not use contraceptive methods, $35(58.3 \%)$ used male condom, and only two patients $(3.3 \%)$ used hormonal contraception. Fifteen women (25\%) had a history of prolonged hypothalamic amenorrhoea, whereas the remaining patients were menstruating regularly. In these latter subjects cervico-vaginal samples were performed 10-20 days after menstruation. Twenty one women (35\%) were at stage C of HIV disease, and $23(38.3 \%)$ had CD4+ cell counts of less than $200 \times 10^{6} /$.

The prevalence of HIV-1 related nucleic acids detection, HPV infection, vaginitis, and Papanicolaou smear findings is reported in table 1 . The mean CD4+ cell count was $360 \times 10^{6} / 1$ (range 41-776). The detection of HIV-RNA in plasma significantly correlated with the presence of proviral HIVDNA in cervico-vaginal secretions (23 out of 27 versus 19 out of 33 , odds ratio $=4.24,95 \% \mathrm{CI}=1.05$ to $18.5, \mathrm{p}=0.03$ ). Lavage samples that tested positive for cell free HIV-RNA and for HIV-RNA transcripts were also positive for proviral HIVDNA. There were no significant correlations between HPV infection or vaginitis and the detection of HIV-DNA in cervico-vaginal secretions (29 out 46 versus nine out 14, $\mathrm{OR}=0.95,95 \% \mathrm{CI}=0.23$ to 3.84 , and eight out 46 versus two out $14, \mathrm{OR}=1.26,95 \% \mathrm{CI}=0.2$ to $9.98, \mathrm{p}=0.87$ and 0.84 , respectively). The prevalence of HIV-DNA detection in lavage samples was $80.6 \%$ (25/31) among women with squamous intraepithelial lesion (SIL) cervical lesions compared with $72.4 \%$ (21/29) among those with negative cytological findings 
Table 1 HIV related nucleic acids, HPV infection, vaginitis, Papanicolaou smear findings, CD4+ cell counts, and cytokine concentrations in cervico-vaginal samples in the study population

\begin{tabular}{lll}
\hline & No & $\%$ \\
\hline Plasma HIV-RNA & $27 / 60$ & 45 \\
HIV-DNA (lavage sample) & $46 / 60$ & 76.7 \\
HIV-RNA transcripts (lavage sample) & $42 / 60$ & 70 \\
Cell-free HIV-RNA (swab sample) & $43 / 60$ & 71.7 \\
HPV infection (lavage sample) & & \\
None & $22 / 60$ & 36.7 \\
6-11 & $7 / 60$ & 11.7 \\
16, 18, 31, 35 & $13 / 60$ & 21.7 \\
Others & $18 / 60$ & 30 \\
Candida infection & $12 / 60$ & 20 \\
Bacterial vaginosis & $3 / 60$ & 5 \\
Trichomonas & $1 / 60$ & 1.7 \\
Papanicolaou smear & & \\
Negative & $29 / 60$ & 48.3 \\
SIL 1 & $29 / 60$ & 48.3 \\
SIL 2 & $2 / 60$ & 3.3 \\
\hline & Mean & Range \\
\hline CD4+ cell counts ( $\times 10^{6} /$ Il) & 360.3 & $41-776$ \\
Plasma HIV-RNA (copies/ml) & 2227.8 & $200-25800$ \\
HIV-DNA lavage sample (copies/10 5 cells) & 69.2 & $5-500$ \\
HIV-RNA transcripts lavage sample (copies/105 cells) & 93.7 & $8-1000$ \\
Cell-free HIV-RNA swab sample (copies/ml) & 374.2 & $20-3500$ \\
TNF- $\alpha$ (pg/ml) & 34.5 & $9.1-155.1$ \\
IL-1 $\beta$ (pg/ml) & 116.8 & $0-916.3$ \\
IL-6 (pg/ml)* & 20.0 & $0-242.5$ \\
\hline *In 14 cases, II-6 was undetectable. & & \\
\hline
\end{tabular}

$(\mathrm{OR}=1.59,95 \% \mathrm{CI}=0.41$ to $6.26, \mathrm{p}=0.547)$. In 14 cases (23.3\%) IL-6 was undetectable. IL-1 $\beta$ and IL-6 levels were significantly correlated (Spearman rho $=0.331, \mathrm{p}=0.024$ ). In addition, IL- $1 \beta$ concentration in lavage samples was directly correlated with proviral HIV-DNA (Spearman rho $=0.35$, $\mathrm{p}=0.01)$, cell associated HIV-RNA viral load in cervicovaginal secretions (Spearman rho $=0.263, p=0.05$ ), and with plasma HIV-RNA viral load (Spearman rho $=0.257$, $\mathrm{p}=0.06$ ).

The associations between cytokine levels in lavage samples and cytological findings or vaginal infection are reported in table 2 . IL- $1 \beta$ concentration was higher among women with SIL, while both IL-1 $\beta$ and IL-6 were lower in patients with vaginal infection in comparison to respective negative controls.

At the time of the study, 50 women (83.3\%) had been receiving stable antiretroviral therapy for at least 3 months. The median duration of antiretroviral therapy was 12 months (range 3-32). Nucleoside analogues (zidovudine plus lamivudine or didanosine) only (26 women), or nucleoside analogues plus indinavir ( 24 women) were the antiretroviral drugs used. Women receiving stable antiretroviral therapy had significantly lower TNF- $\alpha$ (34.4 pg/ml, range 9-155.1 compared to $44.4 \mathrm{pg} / \mathrm{ml}$, range $16.3-104.1 ; \mathrm{p}=0.04$ ) and higher IL-6 levels (24 pg/ml, range 0-242.5 compared to $1.4 \mathrm{pg} / \mathrm{ml}$, range $0-5.3 ; \mathrm{p}=0.004$ ) in lavage samples compared to untreated women. IL- 6 was undetectable in $70 \%$ $(7 / 10)$ of the untreated women and in $14 \%(7 / 50)$ of the women receiving stable antiretroviral therapy $(p=0.001$ by Fisher's exact test).

The analysis of the association between the duration of therapy and HIV and cytokine concentrations in lavage samples confirmed these findings. Duration of therapy was significantly related to the cell free HIV-RNA copy number in lavage samples (Spearman rho $=-0.209, \mathrm{p}=0.027$ ) and to the concentration of IL-6 (Spearman rho $=0.218, p=0.03$ ).

To evaluate the simultaneous associations of clinical and microbiological variables on the cytokine concentration of lavage samples we used stepwise multiple regression models on ordinal categorical variables. The analysis confirmed that independent of the presence of HIV related nucleic acids, antiretroviral treatment correlated inversely with TNF- $\alpha$ and directly with IL-6 cervico-vaginal concentrations (table 3). The presence of cytological SIL was associated with increased

Table 2 Cytological findings, vaginal culture results, and mean cytokine concentrations (range) in cervico-vaginal samples

\begin{tabular}{|c|c|c|c|}
\hline & $\begin{array}{l}\text { TNF- } \alpha \\
(\mathrm{pg} / \mathrm{ml})\end{array}$ & $\begin{array}{l}\text { IL-1及 } \\
(\mathrm{pg} / \mathrm{ml})\end{array}$ & $\begin{array}{l}\text { IL-6 } \\
(\mathrm{pg} / \mathrm{ml})\end{array}$ \\
\hline \multicolumn{4}{|l|}{ Cervical cytological findings } \\
\hline $\begin{array}{c}\text { Negative } \\
\text { Range }\end{array}$ & $\begin{array}{l}32.2 \\
(13.2-76.9)\end{array}$ & $\begin{array}{l}73.4 \\
(0-459.1)\end{array}$ & $\begin{array}{l}16.9 \\
(0-121.2)\end{array}$ \\
\hline & 36.2 & $153.9^{*}$ & $22.4^{*}$ \\
\hline \multicolumn{4}{|l|}{ Vaginal infection } \\
\hline Negative & 36.7 & 144.9 & 23.7 \\
\hline Range & $(9.1-155.1)$ & $(10.2-916.3)$ & $(0-242.5)$ \\
\hline $\begin{array}{l}\text { Positive (candida, vaginosis, trichomonas) } \\
\text { Range }\end{array}$ & $\begin{array}{l}28.3 \\
(13.2-58.6)\end{array}$ & $\begin{array}{l}41.7^{*} \\
(0-136)\end{array}$ & $\begin{array}{l}10.2^{*} \\
(0-121.2)\end{array}$ \\
\hline
\end{tabular}


Table 3 Association between quartiles of TNF- $\alpha$, LL-1 $\beta$, and IL- 6 concentration in lavage samples and microbiological and clinical variables

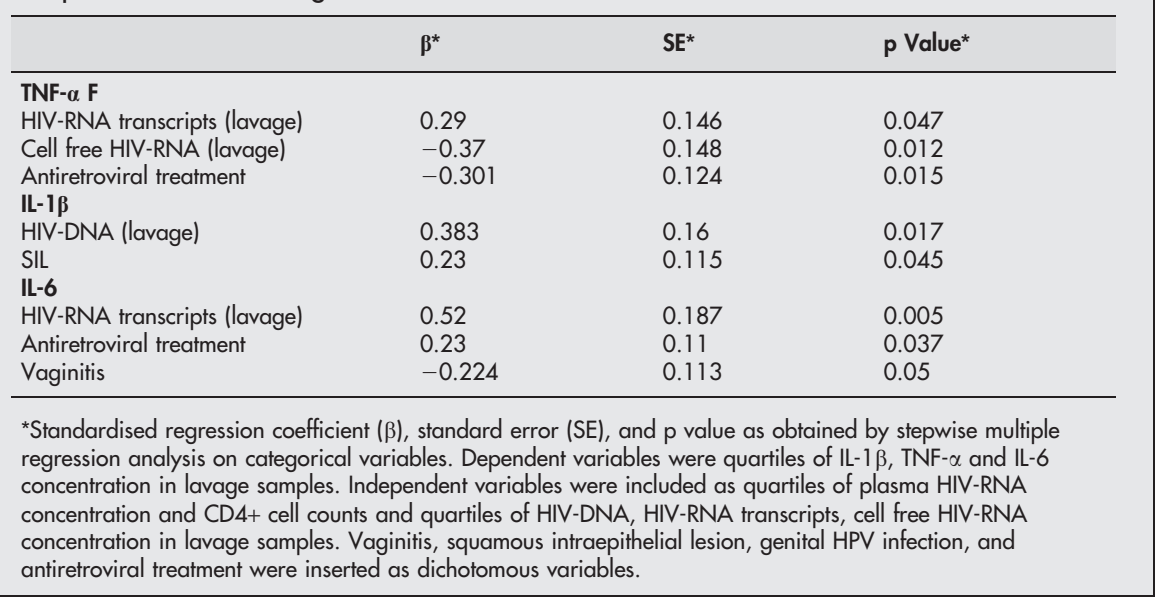

concentration of IL-1 $\beta$ whereas vaginitis was inversely related IL- 6 concentration. Regarding the role of HIV related nucleic acids, multiple regression analysis showed that quartiles of cell associated HIV-RNA viral load in cervicovaginal secretions correlated directly with IL- 6 and TNF- $\alpha$ concentrations. As also evident in univariate analysis, the IL$1 \beta$ concentration in lavage samples was directly correlated with proviral HIV-DNA.

\section{DISCUSSION}

This study showed that the IL-1 $\beta$ concentration in cervicovaginal secretions was significantly correlated with proviral HIV-1 DNA and cell associated HIV-1 RNA viral load detected in the same compartment and with HIV-1 RNA viral load measured in the plasma. In addition, the detection of HIV-1 RNA in plasma was significantly linked to the presence of proviral HIV-DNA in cervico-vaginal secretions. HPV infection or vaginitis did not affect the detection of HIV-1 DNA. On the other hand, cytological alterations of the cervix were associated with higher cervico-vaginal IL-1 $\beta$ concentrations, while both cytokines were lower in patients with vaginal infections.

In women receiving stable antiretroviral therapy, together with a significant reduction of cell free HIV-1 RNA concentration, we were able to demonstrate significantly lower TNF- $\alpha$ and significantly higher IL- 6 concentrations in cervico-vaginal secretions compared with untreated women.

This set of results seems to confirm the knowledge that local immune activation may modulate HIV-l shedding in cervico-vaginal secretion with possible influence on vaginal physiology and host defence.

Several investigations ${ }^{17}{ }^{18}$ have previously shown that the shedding of HIV in the genital tract can occur in $20-30 \%$ of non-viraemic women. Vaginal infection could have a facilitating role in local HIV viral replication and shedding ${ }^{17}$ by interacting with the local mucosal immune environment. ${ }^{26}$ Specific cytokines may then be crucial to the cervico-vaginal presence of HIV. In our study we have considered IL-1 $\beta$, TNF$\alpha$, and IL- 6 because of their clear implication in the modulation of the levels of HIV expression. ${ }^{19}$ TNF- $\alpha$ increases HIV-1 proviral trascription ${ }^{2}$ and both TNF- $\alpha$ and IL- $1 \beta$ can upregulate HIV replication through activation of the LTR promoter region. ${ }^{3}$ In addition, IL- 1 is synergic with IL-6, but not with TNF, in the upregulation of virus expression of the latently infected human promonocytic cell line Ul, as measured by accumulation of steady state mRNAs and production of reverse transcriptase activity. ${ }^{20}$ On the other hand, such cytokines may be differently affected by several cervico-vaginal infections. Indeed, Candida albicans induced considerable levels of TNF- $\alpha$ but not of IL- $6,{ }^{21}$ while aerobic infections were associated with high levels of IL- 6 and IL- $1 \beta$ in vaginal fluids. ${ }^{22}$

The correlation between local IL- $1 \beta$ and proviral HIV- 1 and cell associated HIV-1 RNA viral load in cervico-vaginal secretions emerging from the present study suggests that such cytokines may represent a marker of possible transmission of the disease. On the other hand, other vaginal cytokine levels correlate with vaginal viral load and not plasma HIV shedding, with a significant elevation at the time of menses and no significant changes during other phases of the cycle. ${ }^{23}$

A very interesting finding was the significant higher levels of IL-1 $\beta$ in HIV infected women with SIL. Such data deserve further attention in light of the evidence that HPV infection of the cervix may influence HIV pathogenesis by inducing the production of immune and inflammatory factors that enhance HIV expression. ${ }^{24}$ On the other hand, a highly significant association between high secretor IL-1 $\beta$ phenotypes and LSIL has been reported ${ }^{25}$ while, in another study, TNF- $\alpha$ and IL- $1 \beta$ levels were significantly higher in women with cervical cancer compared with controls and CIN patients. ${ }^{26}$

The presence of vaginal infections seemed to negatively affect the pattern of local cytokines, given the evidence of lower IL-1 $\beta$ and IL-6 concentrations in women with vaginitis. The difficult interpretation of this data may be because it was not the major aim of our study to characterise the cytokine pattern in relation to vaginal infections that were analysed regardless the different aetiologies. Indeed, bacterial vaginosis has been clearly associated with high levels of IL-1 $\beta$ or TNF- $\alpha$ to partially explain the mechanism by which this risk factor enhances HIV transmission. ${ }^{8}$ On the other hand, the use of antiretroviral therapy in the majority of our study population may have altered the finding.

The evidence that stable antiretroviral treatment significantly affected the presence of cytokines in cervico-vaginal secretions and that the duration of therapy was significantly linked to both HIV shedding and IL- 6 concentration, is of great interest when considering the potential significance in term of sexual transmission. Indeed, the higher cervicovaginal levels of IL-6 detected in treated women are consistent with the idea that even though it is considered proinflammatory, IL-6 may exert an anti-inflammatory action under special circumstances. ${ }^{27}$ IL- 6 contributes to the production of several proteins that could function as a protective mechanism. ${ }^{28}$ Moreover, IL- 6 inhibits IL-1 $\beta$ and TNF- $\alpha$ production not only by directly suppressing their 


\section{Key messages}

- Local immune activation may modulate HIV-1 shedding in cervico-vaginal secretions

- Stable antiretroviral treatments significantly affect the presence of cytokines in cervico-vaginal secretions

- In HIV infected women, vaginal infection or squamous intraepithelial lesions (SIL) significantly influence the presence of cytokines in cervico-vaginal secretions

production and release, ${ }^{29}$ but also by stimulating the induction of the IL- $1 \beta$ receptor antagonist and the soluble TNF- $\alpha$ receptor $(\mathrm{p} 55) .^{30}$ Our data showing significantly low TNF- $\alpha$ concentrations in treated HIV infected women are thus compatible with the hypothesis that IL- 6 may exert a local protective action.

In conclusion, markers of cervico-vaginal immunity are relevant to the shedding of HIV in the genital tract. Whether or not specific cytokines may be directly involved in conditioning the risk of sexual transmission of HIV-1 remains to be established. However, there is no doubt that pharmacological agents lowering HIV-1 replication cause a shift to a pattern of cytokine production which seems less favourable to the transmission of the disease.

\section{ACKNOWLEDGEMENTS}

The authors are grateful to $\mathrm{Dr} G$ Randine from the toxicology division, IRCCS Salvatore Maugeri Foundation, Pavia, Italy, for her expert technical assistance in cytokine assays.

This study was supported by RC 1998, IRCCS Policlinico S Matteo, Pavia, Italy.

\section{CONTRIBUTORS}

FZ, laboratory analysis of HIV viral loads, and HPV typing, preparation and discussion of the project, writing of the manuscript; REN, laboratory analysis of cytokine concentrations, preparation and discussion of the project, writing of the manuscript; RB, laboratory analysis of HIV viral loads and HPV typing, preparation of the project, discussion of the methods; RM, laboratory analysis of HIV viral loads and HPV typing, preparation of the project, discussion of the methods; RM, recruitment and evaluation of the patients, performing visits and samples, discussion of the manuscript.

\section{Authors' affiliations}

F Zara, R Brerra, R Migliavacca, Department of Microbiology, University of Pavia, Italy

R E Nappi, A Spinillo, Department of Obstetric and Gynecology, IRCCS S Matteo, University of Pavia, Italy

R Maserati, Division of Infectious Diseases, IRCCS S Matteo, Pavia, Italy

\section{REFERENCES}

1 Iversen AKN, Fugger L, Eugen-Olsen J, et al. Cervical human immunodeficiency virus type 1 shedding is associated with genital beta-chemokine secretion. J Infect Dis 1998;178:1334-42.

2 Crowley-Nowick PA, Ellenberg JH, Vermund SH, et al. Cytokine profile in genital tract secretions from female adolescents: impact of human immunodeficiency virus, human papillomavirus, and other sexually transmitted pathogens. J Infect Dis 2000;181:939-45.

3 Osborne L, Kunkel S, Nabel GJ. Tumor necrosis factor-alpha and interleukin-1 stimulate the human immunodeficiency virus enhancer by activation of the nuclear factor kappa B. Proc Natl Acad Sci 1999;86:2336-40.
4 Poli G, Fauci AS. The effect of cytokines and pharmacologic agents on chronic HIV infection. AIDS Res Hum Retroviruses 1992;8:191-6.

5 Vincenzi E, Poli G. Regulation of HIV expression by viral genes and cytokines. $J$ Leukoc Biol 1994:56:328-34.

6 Lawn SD, Subbarao S, Wright TC, et al. Correlation between human immunodeficiency virus type 1 RNA levels in the female genital tract and immune activation associated with ulceration of the cervix. I Infect Dis 2000;181:1950-6.

7 Spinillo $A$, Debiaggi $M$, Zara $F$, et al. Human immunodeficiency virus type 1 related nucleic acids and papillomavirus DNA in cervicovaginal secretions of immunodeficiency virus-infected women. Obstet Ginecol 2001;97:999-1004.

8 Sturm-Ramirez K, Gaye-Diallo A, Eisen G, et al. High levels of tumor necrosis factor- $\alpha$ and interleukin- $1 \beta$ in bacterial vaginosis may increase susceptibility to human immunodeficiency virus. J Infect Dis 2000;182:467-73.

9 Cu-Uvin S, Caliendo AM, Reinert S, et al. Effect of highly active antiretroviral therapy in cervicovaginal HIV-1 RNA. AIDS 2000;10:415-21.

10 Centers for Disease Control. 1993 Revised classification system for HIV infection and expanded surveillance case definition for AIDS among adolescents and adults. MMWR 1992;41:1-15.

11 Amsel R, Totten PA, Spiegel CA, et al. Nonspecific vaginitis: diagnostic criteria and microbiological and epidemiological associations. Am J Med 1983:74:14-22.

12 Spinillo A, Zara F, De Santolo A, et al. Quantitative assessment of cellassociated and cell-free virus in cervicovaginal samples of HIV-1 infected women. Clin Microbiol Infect 1999:5:605-11.

13 Chomczynski P, Sacchi N. Single-step method of RNA isolation by acid guanidinium thiocyanate-phenol-chloroform extraction. Anal Biochem 1987;162:156-9.

14 Ehrlich GD. PCR-based methods for the detection of the human retroviridae and hepadnaviridae. In: Ehrlich GD, Greemberg SJ, eds. PCR-based diagnostics in infectious disease. Boston: Blackwell Scientific Publications Inc, 1994:415-46.

15 Menzo S, Bagnarelli P, Giacca M, et al. Absolute quantitation of viremia in human immunodeficiency virus infection by competitive reverse transcription and polymerase chain reaction. J Clin Microbiol 1992;30:1752-7.

16 Manos MM, Ting Y, Wright DK, et al. Use of polymerase chain reaction amplification for the detection of genital human papillomavirus. Cancer Cells 1989:7:209-14.

17 Spinillo A, Debiaggi $M$, Zara $F$, et al. Factors associated with nucleic acids related to human immunodeficiency virus type 1 in cervico-vaginal secretions. Br J Obstet Gynaecol 2001;108:634-41.

18 Debiaggi $M$, Zara F, Spinillo A, et al. Viral excretion in cervicovaginal secretions of HIV-1-infected women receiving antiretroviral therapy. Eur J Clin Microbiol Infect Dis 2001;20:91-6.

19 Poli G, Fauci AS. Cytokine modulation of HIV expression. Sem Immunol 1993;5:165-73.

20 Poli G, Kinter AL, Fauci AS. Interleukin 1 induces expression of the human immunodeficiency virus alone and in synergy with interleukin 6 in chronically infected UI cells: inhibition of inductive effects by the interleukin 1 receptor antagonist. Proc Natl Acad Sci USA 1994;91:108-12.

21 Steele C, Fidel PL. Cytokine and chemokine production by human oral and vaginal epithelial cells in response to Candida albicans. Infect Immun 2002;70:577-83.

22 Donder GG, Vereecken A, Bosmans E, et al. Definition of a type of abnormal vaginal flora that is distinct from bacterial vaginosis: aerobic vaginitis. Br J Obstet Gynaecol 2002;109:34-43.

23 Al-Harthi L, Kovacs A, Coombs RW, et al. A menstrual cycle pattern for cytokines levels exists in HIV-positive women: implication for HIV vaginal and plasma shedding. AIDS 2001;15:1535-43.

24 Gage JR, Sandhu AK, Nihira M, et al. Effects of human papillomavirusassociated cells on human immunodeficiency virus gene expression. Obstet Gynecol 2000;96:879-85.

25 Majeed GS, Glew S, Bidwell J. An association between LSIL and the high secretor phenotype of IL-1 beta. Gynecol Oncol 1999;73:359-61.

26 Tjiong MY, van der Vange N, ter Schegget JS, et al. Cytokines in cervicovaginal washing fluid from patients with cervical neoplasia. Cytokine 2001;14:357-60.

27 Richards $C D$, Gauldie J. Role of cytokines in acute-phase response. In: Aggarwal BB, Puri P, eds. Human cytokines: their role in disease and therapy Cambridge: Blackwell Science, 1998:253-69

28 Tilg H, Dinarello CA, Mier JW. IL-6 and APPs: anti-inflammatory and immunosuppressive mediators. Immunol Today 1997;18:428-32.

29 Schindler R, Mancilla J, Endres S, et al. Correlations and interactions in the production of interleukin-6 (IL-6), IL-1 and tumor necrosis factor (TNF) in human blood mononuclear cells: IL-6 suppresses IL-1 and TNF. Blood 1990:75:40-7.

30 Tilg $\mathrm{H}$, Trehu E, Atkins MB, et al. Interleukin-6 (IL-6) as an anti-inflammatory cytokine: induction of circulating IL-1 receptor antagonist and soluble tumor necrosis factor receptor p55. Blood 1994;83:113-18. 